\title{
Looking through the eyes of Job: A transpersonal-psychological perspective
}

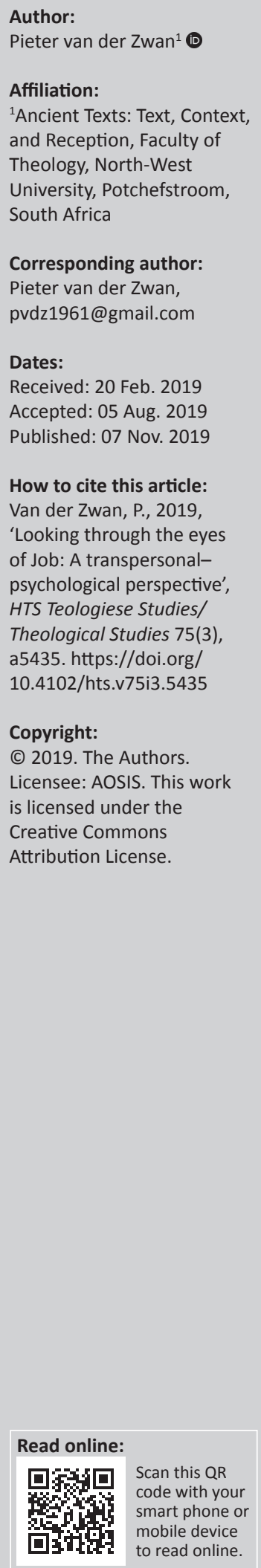

The current context of a turn to the visual and the transpersonal-psychological potential of the book of Job forms the background of this study, which aimed at focusing a psychological lens on the topic of eyes in the book of Job. This approach has the potential of seeing beyond both the literal and the figurative sense of eyes in the book of Job, gaining a vision of a transcendental reality, either in or after this life. In this way, the bodily suffering experienced by the protagonist could be illuminated as a model for every recipient. By relating the eye to other body parts mentioned in the book, a texture of meanings has been woven with a complicated and intriguing subtext for the narrative of the eye in the life of Job. This wealth of value attached to the eye in the book subverts the traditionally negative attitude to the visual in monotheistic religions and resuscitates the eye to the status of even a transcendental level.

Keywords: Job; eyes; transpersonal-psychological; visual; looking; seeing; light; darkness; aniconism.

\section{Introduction}

Within the Hebrew Bible, the eye as one of about 250 body parts mentioned occupies a prominent position. This is also the case in the book of Job, and its significance for the plot and message may therefore be crucial.

The hypothesis here is that the eyes in the book of Job have a transpersonal-psychological meaning; in fact, the eye constitutes the background metanarrative for the foreground plot. Where verses are referred to without mentioning the biblical book in this study, the book of Job is intended.

Firstly, this study will be briefly contextualised in current developments in Western culture. Secondly, it will focus on depth psychological perspectives on seeing. Thirdly, an overview of the visual in the book of Job will be presented before an investigation into its links with other body parts in the book. Finally, drawing all of this together, it hopes to make visible certain previously overlooked transpersonal-psychological dimensions of the eye in the book of Job.

The traditional rootedness of monotheistic book religions in the Hebrew aniconic stance emphasises an obedient ear to the voice and name of the $\mathrm{f} /$ Father. $^{1}$ This culture is now again shifting to the visual, which is, ironically, also accused of dominance. This is especially because of the reifying male gaze as façade for a totalitarian view, all scopic regimes and the commercial exploitation of the visual. Scientific discourse has, for instance, been criticised by Fabian (1984) for its visualism. Visual culture is therefore approached in Visual Studies and, in a narrower way, in Image Studies as a broadening of Art Studies by means of a variety of academic disciplines, often in an interdisciplinary way (cf. Jay 2002:passim). Visual culture studies have become increasingly important in religious studies through the work of David Morgan, Sally Promey, Jeffrey F. Hamburger and S. Brent Plate.

Jay (1993:211-213) notes that French postmodern philosophers and artists have critiqued the dominance of the eye in Western culture as ocularcentrist and raised suspicion over the 'visual turn' in the United States. The allegedly neutral eye's distance from the object seen does not make it more objective, as it always remains a desiring ${ }^{2}$ eye.

This postmodern challenge to the dominance of the eye can then be extended to its hegemonic or at least dominant status in the book of Job as well. This is the case in 3:9, 10, 16, 20; 7:7; 19:26, 27;

\footnotetext{
1.See, for example, Lacan 1981:25, but also his emphasis in the mirror stage (1966:99) on misunderstanding (méconnaissance) and self alienation, and his view of the voice as 'seeing' (1973:46).
}

2.The eye is not just a neutral observer but desiring the objects that it sees, according to both Freud (1942:68-69) and Lacan (2004:49).

Note: The collection entitled 'Eben Scheffler Festschrift', sub-edited by Jurie H. le Roux (University of Pretoria) and Christo Lombaard (University of South Africa). 
21:20; $36: 25$ and especially $42: 5$ with the next verse, 42:6, subtly emphasising it even further, although Schellenberg (2016:117) reminds one that $42: 5$ is meant purely metaphorically, that only the storm can be seen and that the aural experience of God brings certainty. Pelham (2012:77, 205) argues that God does not insist on being seen, but rather that creation be seen. That 4:12, 12:11, 13:17 and 33:16 are positive evaluations of hearing is not completely convincing, as these references to hearing are not weighed against seeing. Yet, the fact that seeing is chosen as a metaphor and explicitly preferred over hearing implies an association between the visual and insight in the Job texts. This preference is further reinforced by the complaint that God's face is hidden in 13:24; 33:26 and 35:14, although God's silence is also bemoaned by Job in 19:7 and 30:20, for instance.

As Seow (2011:84) has pointed out, the 'homographic' wordplays prove that the book of Job was also meant as visual poetry, to be seen, and not only to be heard.

\section{Depth psychological perspective on eyes}

Two prominent psychoanalytical thinkers, Freud and Lacan, are relevant here, as they both took the meaning of the eyes and of seeing seriously. The eyes as erogenous zone in the sense of desiring the object seen (Freud 1942:69) constitute the human developmental advance from touch (Freud 1942:55), taste and smell, represented by the skin, mouth and nose, respectively, where contact is direct, to bridge distance between the subject and the object (List 2013:108). In that sense, the eyes not only remind one of painful separation but also initiate symbolisation in the space where inner and outer realities meet and overlap.

As organs of sensation-seeking curiosity ('Schaulust', Freud 1996:99-100) and exhibitionism, the eyes express partial drives (Freud 1942:68-69), as these drives serve as sexual appetiser ('Vorlust') because of the distance between the subject and the object, whereas 'Endlust' (Freud 1942:109-115) requires contact, in this sense regressing to the senses developed before (vide supra). This double function of the eyes, because of their very strong demands, elicits the defence of the ego-drive interfering with consciousness. The ego represses the forbidden object through blinding the subject. For children, it is a terrible anxiety to have one's eyes damaged, and for many adults, this anxiety has remained as worse than an injury to any other organ. Dreams, fantasies and myths have shown that the fear of becoming blind is often a substitute and displacement for castration anxiety.

Ironically, dreams are seldom experienced other than visually (Hillman 1979:186). Even for Oedipus, it was a concession for the punishment of castration (Freud 2005b:243-244). This psychoanalytic discovery of castration anxiety because of the Oedipal conflict is significant for the book of Job, as no father, but only the mother of Job is mentioned. It seems that Job represses his father by not mentioning him.
The eye can also symbolise genitals (Freud 2008:364), although here he limits it to female genitals. An example from the Hebrew Bible is the symbolic castration of Samson when Delilah cut his hair in Judges 16:19 followed by his blinding in verse 21 , suggesting that the two are somehow connected here. Samson, whose name significantly means 'Man of the Sun' (i.e. a symbol of consciousness according to psychoanalytic thinking), loses his sight and perhaps also insight. According to Neumann (1949:172), patriarchal castration has two forms: an inferior form is where the vital functions are represented by the penis and a superior form where the mental functions are represented by the eyes. The first was symbolically executed by Delilah when she cut his hair, and the second by her compatriots. Likewise in 1 Samuel 11:2, שָָ [Nahash, the same word used for the serpent, a possible phallic suggestion, in Gn 3:1], the Ammonite demands 'sacrificing' an eye as price, seal or proof of sincerity to enter into a contract, just as circumcision symbolised the covenant.

To move from Freud's psychoanalytic understanding of the eyes to that of Lacan (1966:93-95), humans are as infants completely under the influence of the sense of sight when they form a unified image of their bodies during the mirror stage, for which Lacan has become so well known. This mirror image as double assists them to develop a precarious sensual imaginary and narcissistic functioning ego. Narcissism stems from this mirror stage when falling in love with the idealised image is contrasted to the muddled imperfection of the infant's own body. This imaginary constellation gradually withdraws from the symbolic order. The imaginary is the body. The body as a single unit is initially introduced as an image during the mirror stage. This image is the intermediary for the body to participate in the economy of jouissance [enjoyment]. Yet, the body conditions all images. In the illusion of self-omnipotence persisting in its narcissism, the infant is incapable of forming and appreciating relationships with others as different people.

When the traumatic realisation develops that the image is not reality, this narcissism slips from the child's grip - the loss of which opens its eyes, so to speak, to difference and the other (Dolto 1984:28). As such, this double but contradictory experience of recognition reminds one of the roles of the mirror or of the mask in Renaissance art: symbolising prudence and falsehood, respectively. The eyes therefore become very important during the mirror stage, but remain always conditioned and structured by the symbolic order, that is, culture (Widmer 2006:27-28).

The eyes are especially important in paranoia, where they are projected onto objects that become personified (Widmer 2006:126). This reversal is clear when 13:20 and 13:24 are considered: in the first instance, Job claims to hide his face, but in the latter it is actually God's face that is hidden. 


\section{An overview of the visual in the book of Job \\ The eye}

Iִ [eye] is mentioned 46 times (Jenni \& Vetter 1984:260) and so virtually predominates as body part in a narrative where facing the eyes of the Other seems to be the life-threatening or existential challenge. ${ }^{3}$ This dominance of וּיע [eye] in the book of Job agrees with its frequency in the Hebrew Bible where it is as body part also in third position (Baumann 2003:246).

Yet, by reading the text, one hears about the eyes, but one never sees them. So one has to imagine them, make a mental image of them and visualise them. Yet, one remains, in fact, blind to them. A book religion tends to block out the body.

Some additional statistics can draw the contours of the eye's possible meanings in the book of Job. Most important may be whose eyes are mentioned and by whom:

- 31 times by Job, where 12 instances are about his own (so less about himself than those of others: 3:10, 7:7, 13:1, 16:20, 17:2, 17:7, 19:27, 29:11, 29:15, 31:1, 31:7, 42:5), 5 times about God's $(7: 8,10: 4,14: 3,16: 9,24: 23)$ and 14 times about those of others $(7: 8,10: 18,17: 5,19: 15,21: 8,21: 20,24: 15$ [twice], 27:19, 28:7, 28:10, 28:21, 31:16, 40:24)

- 4 times by Eliphaz: his own (4:16), those of Job (15:12), God (15:15) and the humble (22:29)

- 3 times by Zophar: those of God (quoting Job: 11:4), the wicked (11:20) and others (20:9)

- 2 times by Bildad: those of Job (18:3) and God (25:5)

- 2 times by Elihu: in both those of God (34:21, 36:7)

- 2 times by God: in both cases those of animals: the vulture (39:29) and the leviathan (41:10)

- 2 times by the narrator: once about the eyes of Job's three friends (2:12) and in another about those of Job (32:1).

Job's eyes are mentioned 14 and God's 11 times, resulting in more than half of all instances. The rest are scattered amongst the 6 or 7 times about the evil person, 5 or 6 times about those of some unnamed people, ${ }^{4} 4$ times about animal eyes, once those of Job's friends, once those of a widow, once those of a miner, once Eliphaz' own (unique amongst the four advisers), once those of the humble and once those of a household.

That means all interlocutors, except Job's wife, refer to the eyes. Furthermore, Job's and God's eyes are mentioned more often than those of others and also that Job dominates the references to his own eyes and those of God. In his mind, something is therefore going on between his own eyes and those of God.

Sometimes $(11: 4 ; 18: 3 ; 19: 15 ; 25: 5 ; 32: 1$, but in $40: 24$ it is meant in a more concrete way) וּנ [eye] is used with the prepositional

\footnotetext{
3 The roots, used with prepositions to render them as either directional or instrumental indicators where the direct meaning of the body part becomes hidden.

4.This uncertainty is because of the different possible interpretations of the relevant verses.
}

prefix, $ב$, indicating the metonymical meaning of judgement and perhaps even of an evil eye, and once with $ל$ in 21:8, but not in 31:1 where the preposition is simply locational, although Driver and Gray (1977:262) claim that an imposition of a superior party in such a covenant is suggested by $ל$ - [for]. The singular is used 14 and the dual form 32 times.

The minority of cases, where [eye] is mentioned in the Hebrew Bible, are limited to the vision function, many of these referring to a defect (Stendebach 1982:33). Such a reference to bodily vision is also the case in the first mention of eyes in the book of Job, and then by the narrator, concerning those of Job's three friends in 2:12, where their sight fails

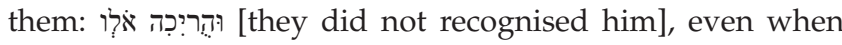
they know that the man they see must be him (cf. Pelham 2012:57). Incidentally, in the end Job discovers that he likewise has not recognised the 'body' of God incarnated in creation and sees God for the first time.

This lack of recognition of God is so different from 29:11 where Job's appearance made the eye that saw him testifying to his exceptional quality. Seow (2011:71), however, interprets רְּעִ (and [when] the eye) as Job's own eye, confirming his (narcissistic?) righteousness when things went well. Just as Job's spiritual myopia in 9:11, Eliphaz cannot make out what appears before him in 4:16 either. Added to that can be 11:20

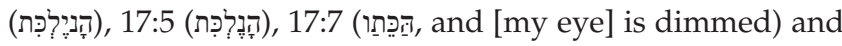

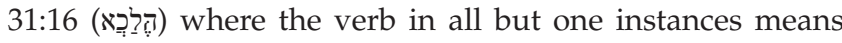
'fail' (being causative in the last instance), as it does in many of these instances. When the internal foetus is opposed to the external world of suffering, then the eyes are polarised over against the womb but paralleled to the latter's so-called doors in 3:10, somewhat echoed in 10:18. That the eye as concrete reference occurs only in the minority of cases means that it otherwise has a strong symbolic significance. In 16:20 (and perhaps in 17:2, 7), יניע. [my eye] is associated with crying, suggesting a fountain and therefore the other meaning of the word, וּ, and in 22:29 the humble lower their eyes as a sign of their attitude. The eyes therefore often express weakness and vulnerability, also emotionally.

The eyes' direct experience equalises people through common sense in 13:1 (Jones 2013:847). Even when the eye simply sees, its observation is temporary as its objects are transitional, if 20:9 is generalised. Being seen here means being alive.

In 29:15, Job claims to have been eyes for the blind, just as he used to be the feet for the lame. From head to toe, he has served as compensation for broken bodies. His eyes could here be like witnesses (Stendebach 1982:34) but now are healthy organs. On the contrary, he wonders if he might not have caused the widow's eyes to have failed her in 31:16.

In 39:29, the vulture's eyes are idealised, but perhaps also suggesting an evil eye.

Likewise the behemoth's eyes seem to be too strong to be captured in 40:24, and in 41:10, the eyes of the leviathan are 
compared to the early morning sun, just as in 3:9. In Egyptian hieroglyphics, a crocodile's reddish eyes, seen before its body became visible, were similarly interpreted as suggesting dawn (cf. Ross 2010:208-209). Here close to the end, God turns the words of Job's opening speech in Chapter 3 around and this includes the eyes that Job denigrated.

Yet, this idealisation of the eyes of animals has its limits as the falcon in 28:7 cannot see into the darkness of a mine. By casting light on the hidden, the human miner can see all precious things in 28:10, where [ְִָ [and every] intensifies and absolutises the penetrating power of the miner's eye. Jones (2009:58) notices the possible pun which וניע [his eye, or: his fountain] in the second colon of the couplet can have when it is paralleled with [ירוֹ [channels] in the first colon, which, in turn, puns on רוight] in 28:11. This suggests that the eye is related to sources of water required for survival. In 28:7, the birds suffer from nearsightedness because, despite their height, they do not see wisdom, and in 28:8, the beasts seem to be farsighted, according to Jones (2009:92). Yet, compared to the transpersonal insights of Wisdom, human eyes are simply not strong enough, according to 28:12. God sees beyond it all according to $28: 24$, although it is not because 'of God's superior eyesight', but because wisdom is not an object to be seen (Newsom 2003:303).

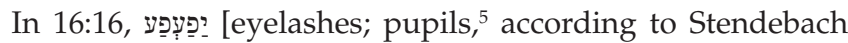
1982:33] is closely connected to the eye, but form a contrast to it by overshadowing the light. However, in 3:9 and 41:10 (as if framing the book), the anthropomorphic use of רעפע as eyelids of the dawn probably refers to sunrays, metaphorically depicted as wings, according to Tur-Sinai (1967:59). Seow (2011:76n55) regards חעפע as the eye in totality as image of a celestial body. Jacobsen and Nielsen (1992:201-2n20) translate it as 'eyelashes', suggesting the streaks of light at dawn.

The dawn is therefore the eye peeping over the horizon, which, however, does not receive but produce the light.

One need not interpret the eyelashes of dawn in 3:9 and 41:10 as personification, as the 'speculative thought' at the time understood nature as 'personal other', according to Laato (2008:57-58).

Supreme remain the eyes of God whose inspecting and testing look can be dangerous, even when Job accuses God of pretending to be merely human by looking for information: in 10:4, the rhetorical question suggests that God's eyes are different from those of humans. Here they are probably linked

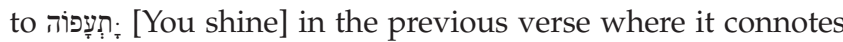
anger. Jones (2013:853) regards God's eyes as the most brutal amongst God's weapons. God can, by implication, also have closed eyes and opens them in judgement, according to 14:3, and in 16:9 God may be the adversary whose evil eye afflicts the victim as with sharpened teeth. The omniscient eyes of God even beyond human death are confirmed in 34:21.

\footnotetext{
5.Noegel (2007:559n7) also argues for this translation because of the Ugaritic cognate ' $p$ ' $p$ (eyes, pupils, eyeball). This translation also makes more sense in all the biblica instances: Jeremiah 9:17; Psalm 11:4, 132:4; Proverbs 4:25, 6:4, 6:25, and 30:13.
}

\section{Seeing and looking}

Eyes are not mentioned but implied in, for instance, 3:9, 4:8, $7: 8,10: 15,11: 11,20: 17,31: 4,31: 26,33: 21,33: 28,34: 26,37: 24$ and 42:5 where the verb, isee], is used. Derived from this verb is the adjective, הִארוּ [seeing], in 10:15, the nouns,

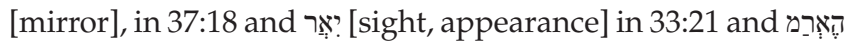
[sight, appearance, vision] in 41:2. In 4:13, 7:14, 8:17 15:17, 19:26, 20:8, 23:9, 24:1, 24:7, 27:12, 33:15, 34:32 and 36:25, the verb, הזוֹיזִז [vision] in 4:13 (Eliphaz), 7:14 (Job), 20:8 (Zophar about the wicked), 33:15 (Elihu about God speaking). In 7:19 and 14:6, the verb, העש [gaze], is used, and in 6:19, 28:24, 35:5, 36:25 and 39:29, the verb טבנ [look] is used. The verb ויב (vide infra; discern, understand, know, observe, perceive [sensory]) has a more fluid meaning, often linking it to insight and is found in $6: 24,9: 11,11: 11,14: 21,15: 9,18: 2,23: 5,23: 8,23: 15,26: 14$, 28:23, 30:12, 31:1, 32:8, 32:9, 32:12, 36:29, 37:14, 38:18, 38:20 and $42: 3{ }^{6}$ This plurality of verbs with different connotations and nuances used for visual observation suggests it as a pervasive background theme in the book.

It is with the invisibility of God that Job is struggling. In 23:

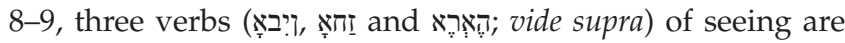

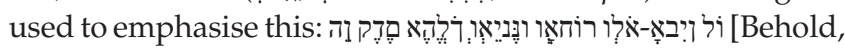
I go forward, but he is not there, and backward, but I cannot

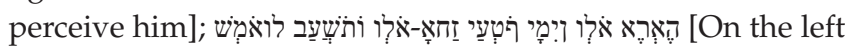
hand, when he does work, but I cannot behold him, he turns himself to the right hand, but I cannot see him]. This invisibility of God makes him also blind to the meaning of his suffering, although his earlier prosperity never seems to have made him blind to God (cf. 1:5). He does not go to a sanctuary or temple to 'see' God, as is often the case in the Hebrew Bible (cf. also Ps 17:15), lift his eyes to heaven as in Psalm 121:1 or fail by seeing a false image of God in icons, prohibited by Exodus 20:4-5 and Deuteronomy 5:8-9.

Finally, one wonders whether the name of the last of Job's

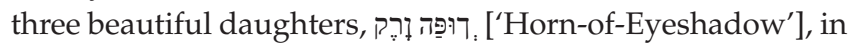
42:14 (cf. 2 Ki 9:30) is coincidental when the eye plays such a significant role in this book.

Clines (2011:1238) also recognises this daughter as representing sight, when her sisters represent hearing and taste or smell.

\section{Light versus darkness polarities}

Visual polarities play an important role in the book, beginning with Job's first speech in Chapter 3. Just the root, רשח: [dark], occurs 26 times, sometimes even clustered with לֶפ (thick darkness), which is found 6 times and תָוְמָלָצ death] in 11 instances, adding additional shades to this idea and suggesting its importance. In 28:3, humans believe they put an end to darkness in mining, here compared to a powerful breakthrough of water (cf. Van Wolde 2003:29), reminding of the birth process. In 38:19, however, God asks rhetorically exactly if humans know where darkness and light have their place.

6.In 13:1 it means "listen", and in 6:30, taste, however. 
These instances of darkness can be contrasted to $[$ light], found 32 times, sometimes together with its opposite, such as in 38:19 where these two extremities may be used as a merism. One can add here also references to the shining sun and bright moon, as in 31:26 (cf. 29:3 and 41:10) - although this is undermined in the eyes of God in 25:5 - and the adjective, רָקָ [splendid, bright], in 31:26, all adding to this sense of light.

דליליל The wight], occurs 17 times over against סוֹי [day] mentioned in 63 instances, although some of these are often negatively connoted and not referring to light, reinforces this tension.

\section{The link of the eyes with other body parts in the book of Job The skin}

Both the eyes and the skin, another important body part in the book of Job, are visible to the external world and are organs of contact and conflict. The eye is an orifice in the skin like a window (which can symbolise the eye [Freud 2005a:61]) in a wall, making this access to the o/Other even stronger. Both these body parts are also problematised, even when the skin is less often mentioned explicitly. In 19:26-27, Job is willing to lose his skin in order that he can see God, even when his eyes are not explicitly mentioned. Losing his body and other boundaries, his eyes will be opened to God. Before the skin, the womb used to be some kind of 'skin'.

\section{The womb}

Just as the eye is etymologically associated with a fountain or spring in the word, וביע [cf. Jeremiah 8:23], so a womb is perhaps

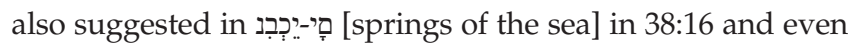

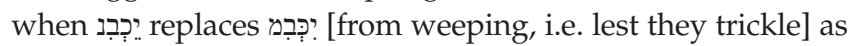
a textual emendation in 28:11 (cf. Dt 33:18; Pr 5:16, 18).

The opening eye(lid)s of dawn in 3:9 and 41:10 (as if framing the book), which, however, not only receive but also produce the light, may poetically be seen as a kind of birth from the dark womb of the night.

The eyes are juxtaposed to the womb in 3:10, just as in 10:18, where the eyes are, however, those of others. Eyes are in any event closely linked to birth, as if sight is born from the darkness of the perhaps even idealised womb. Leaving the womb opened Job's eyes to affliction in the world. That is why Job wants to see God either beyond it or by regressing to the womb, which is equalised with a romanticised death.

Both the psychic significance of the womb and the skin has to do with exclusion and separation, an obviously Oedipal issue where the father's interference interrupts the close bonding, which the infant used to have with only its mother. The eyes bridge this distance, even across the separation rendering God invisible, who has somehow excluded Job from contact (cf. 13:24).
The 'womb-mine' in 28:3, a death from which precious things are 'born', can be penetrated by human eyes that can pierce its לְפ [thick darkness] in 28:3 (cf. also 28:10, 11). In this way, they seem different from the eyes that are confronted with harsh reality outside the womb, according to 3:10.

Libidinal seeing, or the desiring eye, is archaic with sadistic and incorporative qualities (vide infra). This corresponds with Klein's $(1984: 94,96)$ recognition of a phantasy of wanting to enter the womb in an oral-destructive way, followed by anxiety of a similar revenge, also the anxiety of one's own destructive impulses against the womb and of the revenge of being devoured or early death of mother. There might be an inner conflict of wanting to see into the maternal body but without sadism (Fenichel 1998:393-394). Peeping into and penetrating the womb with the eye is a phantasy of those who are fascinated and curious about the dark recesses of their origin and might be beyond Job's urge to see God. This possibility is strengthened by Hamman (2000:269-271), pointing out that Job regressed to dependency expressed by the oral symbolism in his phantasies.

\section{The mother's breasts}

The proximity of the eyes to the breast (cf. also Schellenberg 2016:117) is somewhat veiled in 3:10-12 where the two body

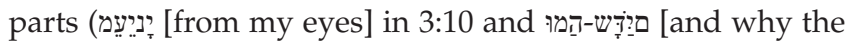
breasts] in 3:12) are not in juxtaposition but separated by verse 11. In 24:9, تשָמ [from the breast] might help to explain why this body part is only mentioned twice ${ }^{7}$ in the book. In both cases, the breast is negatively contextualised. It is important to raise the question why the breast is seemingly neglected in a text where the womb is so important, despite the sidelining of women, with the exception of the 42:13-15.

More than half a century ago, psychoanalysis discovered the close unconscious link between these two body parts in the mind of the infant. Almansi (1960), building on research conducted during the fifties, shows that the two percepts fuse, but that the mother's breast screens the face that is the first to be noticed. These findings stem from clinical case studies (s. 44-58), art (Almansi 1960:58-60), linguistic curiosities (Almansi 1960:60-61) and archaeological discoveries (Almansi 1960:61-65).

Apart from the eyes that correlate with the nipples and dominate the Gestalt of the face, the other facial details remain relatively irrelevant. The mutual identification and ultimate equation of the eyes and the breasts boil down to condensation (Almansi 1960:65, 66), so that the one can function as a metaphor for the other: the one reminds of the other.

The eyes are more strongly cathected, that is, invested with psychic energy, than the breasts. The overwhelming nature of the eyes probably derives from the infant's experience of the maternal eyes as omnipresent and therefore omniscient.

7.When ?ִ [my bosom] in 31:33 is taken as gender-neutral. 
They could function as mirrors to the observer and serve as self-confirmation as well.

It is originally during the oral phase when the maternal eyes are, in fact, more than mirrors: when looking coincides with being looked at and so 'embodies both an identification and a projection', a kind of imitative magic (Almansi 1960:68). The eyes and the mouth are then also unconsciously linked so that the eyes incorporate and 'devour' the beloved (Almansi 1960:69; vide infra).

\section{The genitals}

In Freud's Traumdeutung (2008:401), the eyes can also have a symbolic penis meaning; but in many cases, the eyes also have oral sadism (vide infra) cooperating with it, so a double role. Abraham (2017:18) asserts the bisexual including the vaginal and therefore feminine nature of eyes (cf. also Fenichel 1998:383).

When the eye is psychoanalytically related to the male genital and the threat of castration (vide supra), Job's 'blindness' to God (vide supra) might suggest precisely this subtext. Even when not explicitly stated in 28:21 where humanity is said to be blind to wisdom and in 29:15 where the stem, רִ̣ [blind], appears the only time in the book, the theme runs throughout the whole narrative.

\section{The mouth}

Otto Fenichel (1998:382) links sight to the oral universe, both penetrating and sucking, especially when there is a symbolic equation (Segal 1957:393-395) between looking and devouring. Through magical thinking, a glance can become a sadistic, phallic weapon with which it enchants its sacrifice through staring it into defence paralysis, so that it cannot move before being devoured.

Looking as erasure of the boundary between self and notself, and so identification with the other, has several meanings in the unconscious: devouring, imitation and making the other to imitate. This might be the reason why Job has been unable to see God: looking at God is forbidden, as it involves identification. Such imitation involves the stolen glory of God and as partial drive it can lead to fixation. That Job cannot 'see' God might then be because of him not recognising God.

In primitive object relation, before love and hate, the object is psychically 'incorporated', thus a feminine orientation (Fenichel 1998:387). The eyes and ears are therefore phantasised as object-incorporating sexual organs. Ocular introjection linked to the oral as first relation to the object world is through identification.

That the mouth occupies the fourth place of frequency in the book of Job might therefore not be coincidental, compared to its frequency in the Hebrew Bible where it is in seventh position (Baumann 2003:246). In fact, there is a strong concentration on the oral which includes [mouth, 36 times of which a third is in the mouth of Job], הדָָָש [lip, 12 times],

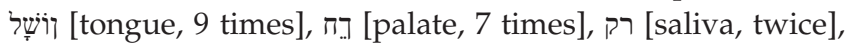

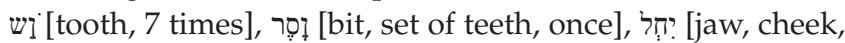
תwice] and תוֹעִלְת [jaw, once]. In total, this constitutes 77 explicit references to the oral area. This is to be expected in a book where oral-sadistic arguments feature strongly in debates constituting most of the content.

Just as with the eye, the mouth or a part of it is explicitly referred to by all interlocutors excluding Job's wife and by the narrator. As with the eye, most of it concerns Job (31 of which 18 times in the mouth of Job himself) and Job also mentions it the most: 33 times.

By projecting his anxiety of seeing God, Job might be avoiding the devouring eyes of God.

\section{Transpersonal-psychological dimension of the eyes in the book of Job}

Transpersonal psychology, focusing on the spiritual and transcendent aspects of human experience, may be relevant for Job's urge to see God. One of the main exponents of this school of modern psychology, Ken(neths) Wilber (1979:3, passim), spoke of the three eyes of the soul, being sensory, mental and transcendental or those of flesh, reason and contemplation, as possible routes to knowledge, not to be confounded with each other.

Job is usually not seen as a prophet or seer. Yet, his ultimate striving or even prediction is precisely to penetrate visually into the transcendent according to $19: 26,27^{8}$ and acknowledged by Elihu in 35:14 which is eventually fulfilled in 42:5, ${ }^{9}$ a theme picked up from Chapter 28 (Peels 2008:195). That the last-mentioned verse only suggests the proximity or immediacy of God which Job experiences, as Peels (2008:196) and LaCocque (2007:92), respectively, claim, is not necessarily true. Neither is Lasine's (1988:44) assertion that it is not God but the cosmos through God's eyes that Job sees, valid. Van Wolde (1994:232) mentions a third possibility, accepted by Van Hecke (2011:397; cf. also Van der Lugt 2014:626): that Job is now seeing through God's eyes. Even this is a leap from what the text states: that Job sees God with his (own) eyes.

It is questionable if the word, ינינ: [and my eye] in 19:27 (and יניע: [my eye] in 42:5), fits a metaphorical reading so that understanding rather than literal seeing is meant (cf. Loader 1992:346). It seems as if the mention of the physical organ insists on a literal interpretation, especially when LeCocque's translation of ירָשְׁבְמוּ. 19:26 is accepted as 'and in my flesh', that is, before death (2007:92; Van der Lugt 1995:227n9), and not 'without my flesh', that is, after death, as Spronk (1986:312-313) understands it under the influence of 17:16.

8.Verses which Gradl (2001:189) regards as amongst the best known in the book of Job and even in the Hebrew Bible.

9.Cf. Exodus 33:20-23, Numbers 12:8, Isaiah 6:1, Amos 9:1, Ezekiel 1; 11, etc. 
When the former meaning is accepted here, it does not exclude Job's belief about an existence after this life, but just that it is not mentioned or meant here, as Ross (2010:107) also sees it. This is how Pope (1973:147) interprets it when he accepts the emendation, ירשבמ [refleshed by him], by Dahood, as the pu'al-participle form of the verb, רשב [enflesh], with the suffix as dative of agency, and as an adumbration of Paul's views in 1 Corinthians 15 . The former meaning would, however, seem to mean, firstly, that Job's skin is, significantly, his body part blocking him from seeing God, and, secondly, that he will see God apparently from his flesh, that is, not (only?) from his eyes as the next verse contradictorily states. One therefore wonders if Job's total bodily experience of God is here intended.

Ross (2010:105) also agrees with the usual meaning of $מ-$ as 'from' here and confirms seeing God as the privilege of the righteous, according to 33:26 (cf. also Ps 11:7).

Ross' view that [חקח [I will see] in 19:26 is to be distinguished from the usual verb for seeing in Hebrew, האר, in that the former refers to something more intellectual or to 'visions of divine origin' is immediately undermined by his own referral to 33:26 where the verb, ארָי [and he sees], is, in fact, used with a similar meaning. In addition, the two verbs are used in a parallelism in 19:26-27, suggesting that they are synonyms here.

Furthermore, האר is also used in the key verse, 42:5, an echo

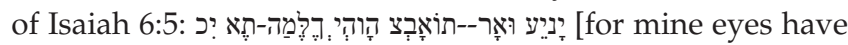
seen the King, the LORD of hosts]. The experience of God in the last Chapters 38-42 is, according to Ross, one of seeing

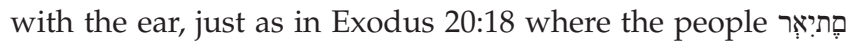
[have seen] that God have spoken to Moses (cf. here also Ps

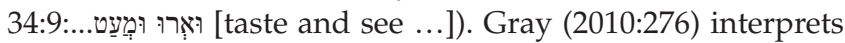
in 19:26b as a confrontational facing of God, which Job so desires. He also notes the repetition of the root, הזח [see], in $19: 26 b$ and 19:27a as exceptional to Job and understands it as intensification to suggest 'vision beyond the superficial'. It is not clear how he relates this stem as a homonym to (breast) in Exodus 29:26, 27, Leviticus 7:30 (twice), 31, 34, 8:29, 9:20, 21, 10:14, 15, Numbers 6:20, $18: 18$ and 19:19, thus only occurring in the Priestly source, and then only of sacrificial animals as wave-offering. He mentions this in the context of Job favoured wordplay, and one wonders if there should be any link between this looking and the breast (vide supra), although here it concerns that of animals. This could still have some hidden, unconscious reference to the human maternal breast.

Ross then refers to Kochan (1997) to assert that seeing in the Hebrew Bible and later is associated with idolatry.

Ross' (2010:106) comment on ? [for myself] in 19:27 as also possibly meaning 'on my side', suggesting God's support, is not convincing. This verse continues by mentioning Job's

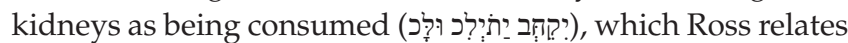
to the tone of a yearning lover, which - quite important characterises the nature of what and in which way Job would be seeing. This would be a relational, not an objective, distanced seeing.

Yet, seeing God is also problematic as God is, in the first place, not to be seen, according to Exodus 33:20, and secondly, usually regarded as invisible, perhaps because nowhere in the Hebrew Bible is God said to have flesh.

Incidentally, flesh is here in 19:26 also related to seeing, that is, some kind of 'eye', as it is in 10:4 but then in an opposite way as the rhetorical question suggests that God's eyes are not of flesh, and see deeper and farther (Clines 1989:245-246). There seems to be an opposition between the eye and the flesh and the skin, just as is the case with the opposition between the womb and the eyes (vide supra) in 3:1 and the heart and the eyes in 31:7.

It is, however, the ears and the eyes which are explicitly related. In 13:1 and 29:11 hearing and seeing have the same status, although in the former case his 'ear' sounds like going further than the seeing of his 'eye' in that it has processed his experiences. Clines' (2006:988) distinction between the beneficiaries and others who praised Job for his favours in the latter case does not stem from the text. It was not suffering as such which opens the eyes of Job to the transcendent, but, ironically, hearing God's voice. This reminds one of Socrates' invitation: 'Speak, that I may see you'.

LaCocque (2007:92), unlike his previous publication (1996:83), emphasises that 42:5 uses only the singular and so adds a dazzling effect to the theophany. The change in Job is, however, from ignorance, not guilt, to personal recognition ${ }^{10}$ and (in)sight (cf. Guillaume 2008:494). Incidentally, the lastmentioned verse is regarded by Tur-Sinai (1967:201) as an indication of the source of the book.

Fyall (2002:178) deals with two questions here: in what sense is Job seeing, and what is the object of him doing so? This last referral to seeing in the text is according to him about a vision of the difference between God and the adversary (Fyall 2002:47) and more than the purely physical seeing spoken of in 19:26-27.

The etymological link between the visual and wisdom in the Indo-Germanic languages is paralleled by the eye as symbol for knowledge and insight in Biblical Hebrew as well, for example, in Genesis 3:6, 7, where wisdom and shame are connected to the eye. In Isaiah $44: 18$, eyes are linked to the heart in the sense of consciousness, different from 1 Samuel $16: 7$ where the two are opposed, as the implied ideal is in Job 31:7, even when it said that they are cooperating. This apparent negativity towards or avoidance of the eyes is perhaps exemplified in the book of Job where God never speaks about Job's eyes but neither about God's own eyes! Is God blind (to him) or are the eyes of Job just so transparent that God can see right into his heart? Yet, in 7:8, Job is aware of God's eyes. When it is about Job's eyes, it concerns his 10.See also in $7: 7,7: 8$; $10: 18,13: 1,19: 27,20: 9,28: 10$ and $42: 5$ as more examples of this possibility. 
clean conscience or at least his self-righteousness in 32:1, although all living eyes are blind to wisdom according to 28:21. The superego as conscience or inner observers and judge is therefore related to the eyes, as is also the case in $31: 1$, but here the eyes are the judged $i d$ : one can infer that Job is watching his own eyes lest they be seduced, as the possibility mentioned in 15:12.

Incidentally, Balentine (2006:477-478) points out that תירְּב [covenant] in 32:1 is a heavily laden concept in the Hebrew Bible, but that it only occurs 3 times in the book of Job, and then always with natural phenomena, where one could risk understanding as natural impulses. The covenant could, therefore, have the same function as the ego, mediating between two 'unequal' pairs of eyes.

As socially judged and humbled eyes in 22:29, they are also seen, recognised and 'raised' by God. It is this judgemental eye that the adulterer wants to escape in 24:15 where his own eye is also on the lookout for that condemning eye and waits for [השֶ] [(the) twilight]. Eyes are therefore constantly watching each other. In 18:3, even Job's own eyes look down in judgement on others as well.

The eyes also access different states of consciousness as in 4:16 where Eliphaz had a probably deceptive vision, something which Stendebach (1982:40) interprets as psychosomatic.

In 27:19, a reference to death could be implied as a formerly rich man discovers the loss of his wealth or of himself not

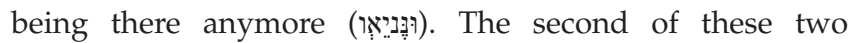
possibilities offered by Rashi (Ibn 'Adoniyah \& GoshenGottstein 1972) would, however, raise questions because the deceased man can still open his eyes and so must be 'there' with some kind of body, even in another reality. This would seem to contradict 14:7-22, where human death is portrayed as the end, although hope for release from it is also expressed.

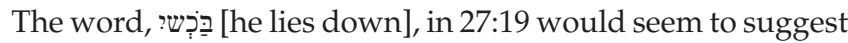
death (cf. Habel 1985:387), although in 3:13 it simply refers to sleep. The euphemistic way of using this word blurs the difference between sleep and death, so that this state of (un)consciousness would still allow the eyes to see. In this way, the death longed for is at the same time also denied. Therefore, Freud (1940:288) regards death as an abstraction with negative content and without an unconscious correlative.

The opening of the doors of the perhaps ideal womb ejects Job and opens his eyes like windows to the harsh realism of the external world. This might have been unconscious all along but with the breakdown of ego-boundary defences in crises Job's unconscious, repressed anxieties surface into consciousness. When his so-called three comforters, who turn out to be his accusers, are, in fact, his projected shadows of guilt, which he, in an almost paranoid way, regards as his enemies, his recourse is to see differently. These shadows block and separate Job from the divine vision to apply the insight of Jung in his answer to the theologian Victor White
(Edinger 1992:85; cf. Canfield 2006:622). Alternatively, as Blake (1995:passim) portrays it, Job's dark unconscious is projected as the negative side of God. That means that Job insists on seeing God from the depth of his unconscious, exactly what Hillman (e.g. 1979:128) argues for, when he reinterpreted and critiqued the Jungian tradition in a postmodern, deconstructive style, arguing for a perspective from below. His view is therefore also the opposite of Lasine's insistence that a bird's, instead of a worm's, eye view is propagated in the book of Job.

Job's apparent death wish is an illusion as he regards it as sleep according to 3:13 and so defends himself against the reality of death (cf. Roy 1991:151).

\section{Conclusion}

This study has started off from a brief overview of the current context in which the book of Job is read in the western world. This has then been narrowed down to highlight psychoanalytical views about the eye. Against this background, the book of Job has been scanned for its explicit and implicit references to the eye: firstly as body part, secondly in its action as looking and seeing, and thirdly as distinguishing between light and darkness. This was followed by linking the mentions of the eye to other body parts, especially the skin and the womb, to deepen and broaden the meaning of the eye into a transpersonal realm where God is ultimately the desired object of experience.

Job first mentions his eyes in 3:10 when they see לִָ [trouble] as first and probably only object after birth. This has been Job's sole source of suffering, even when it is a summary of all his problems. That is caused by leaving the womb, not by being conceived, and so his possible longing back to the womb, where he could have stayed for ever as in a grave, may be related to his longing to see God in 19:26-27, where it is mentioned 3 times, eventually fulfilled in $42: 5$. If his longing is for the womb, then it means that he simultaneously longs for the time when his eyes were still closed to the external world, in the darkness, where he might see God.

\section{Acknowledgements Competing interests}

The author has declared that no competing interests exist.

\section{Author(s) contributions}

P.v.d.Z. is the sole author of this research article.

\section{Ethical consideration}

This article followed all ethical standards for a research without direct contact with human or animal subjects.

\section{Funding information}

This research received no specific grant from any funding agency in the public, commercial or not-for-profit sectors. 


\section{Data availability statement}

Data sharing is not applicable to this article as no new data were created or analysed in this study.

\section{Disclaimer}

The views and opinions expressed in this article are those of the author and do not necessarily reflect the official policy or position of any affiliated agency of the author.

\section{References}

Abraham, K., 2017, Traum und Mythos: Eine Studie zur Völkerpsychologie, Edition Geheimes Wissen, Graz.

Almansi, R.J., 1960, 'The face-breast equation', Journal of the American Psychoanalytic Association 8, 43-70. https://doi.org/10.1177/000306516000800102

Balentine, S.E., 2006, Job, Smyth \& Helwys, Macon, GA.

Baumann, G., 2003, 'Das göttlichen Geschlecht. JHWHs Körper und die Gender-Frage', in Hedwig-Jahnow-Forschungsprojekt (ed.), Körperkonzepte im Ersten Testament. Aspekte einer Feministischen Anthropologie, pp. 220-250, Kohlhammer, Stuttgart. Blake, W., 1995, Illustrations for the book of Job, Dover, New York.

Canfield, G., 2006, 'Response to Fred Johnson's 'A phonological, existential analysis of the book of Job', Journal of Religion and Health 45(4), 619-627. https://doi. org/10.1007/s10943-006-9042-9

Clines, D.J., 1989, A. Job 1-20, Word Books, Dallas, TX.

Clines, D.J.A., 2006, Job 21-37, Nelson, Nashville, TN

Clines, D.J.A., 2011, Job 38-42, Nelson, Nashville, TN.

Dolto, F., 1984, L'image inconsciente du corps, Seuil, Paris.

Driver, S.R. \& Gray, G.B., 1977, A critical and exegetical commentary on the book of Job: Together with a new translation, Clark, Edinburgh.

Edinger, E.F., 1992, Transformation of the God-image: An elucidation of Jung's answer to Job, Inner City Books, Toronto.

Fabian, J., 1984, 'The other and the eye: Time and the rhetoric of vision' Communication. Information Médias Théories 6(2), 290-322. https://doi.org/ Communication. Information

Fyall, R.S., 2002, Now my eyes have seen you: Images of creation and evil in the book of Job, InterVarsity Press, Downers Grove, IL.

Fenichel, O., 1998, 'Schautrieb und Identifizierung', in Aufsätze I, pp. 382-408, Psychosozial, Gießen.

Freud, S., 1940, 'Das Ich und das Es', in Gesammelte Werke chronologisch geordnet, Band XIII: Jenseits des Lustprinzips; Massenpsychologie und Ich-Analyse; Das Ich und das Es, pp. 235-289, Edited by Anna Freud. S. Fischer, Frankfurt am Main.

Freud, S., 1942, 'Drei Abhandlungen zur Sexualtheorie und verwandte Schriften', in A. Freud (ed.), Gesammelte Werk chronologisch geordnet, Band V: Werke aus den Jahren 1904-1905, pp. 27-145, S. Fischer, Frankfurt am Main.

Freud, S., 1996, 'Die psychogene Sehstörung in psyhoanalytischer Auffassung', in A. Freud (ed.), Gesammelte Werke chronologisch geordnet, Band VIII: Werke aus den Jahren 1909-1913, pp. 93-102, S. Fischer, Frankfurt am Main.

Freud, S., 2005a, 'Aus der Geschichte einer infantilen Neurose. VII: Analerotik und Kastrationskomplex (103-121)', in A. Freud (ed.), Gesammelte Werke chronologisch geordnet, Band XII: Werke aus den Jahren 1917-1920, pp. 27-157, S. Fischer, geordnet, Band $X 11$.
Frankfurt am Main.

Freud, S., 2005b, 'Das Unheimliche', in A. Freud (ed.), Gesammelte Werke chronologisch geordnet, Band XII: Werke aus den Jahren 1917-1920, pp. 227-268, $\mathrm{S}$. Fischer, Frankfurt am Main.

Freud, S., 2008, 'VI: Die Traumarbeit. E. Die Darstellung durch Symbole im Traume weitere typische Träume', in A. Freud (ed.), Gesammelte Werk chronologisch geordnet, Band II/III: Die Traumdeutung. Über den Traum, pp. 283-512; 355-409, S. Fischer, Frankfurt am Main.

Gradl, F., 2001, Das Buch ljob, Verlag Katholisches Bibelwerk, Stuttgart.

Gray, J., 2010, The book of Job, Sheffield Phoenix Press, Sheffield.

Guillaume, P., 2008, 'Dismantling the deconstruction of Job', Journal of biblical literature 127(3), 491-499. https://doi.org/10.2307/25610135

Habel, N.C., 1985, The Book of Job: A commentary, Westminster Press, Philadelphia, PA.

Hamman, J.J., 2000, The restoration of Job: A study based on DW Winnicott's theory of object usage and its significance for pastoral theology, Unpublished PhD dissertation, Princeton Theological Seminary.

Hillman, J., 1979, The dream and the underworld, Harper \& Row, New York.

Ibn 'Adoniyah, Y.H. \& Goshen-Gottstein, M.H. (eds.), 1972, Mikṛa'ot gedolot: Torah Nevi'im u-Ketuvim, Makọr, Jerusalem.

Jacobsen, T. \& Nielsen, K., 1992, 'Cursing the day', Scandinavian Journal of the Old Testament 6(2), 187-204. https://doi.org/10.1080/09018329208584991
Jay, M., 1993, Downcast eyes: The denigration of vision in twentieth-century French thought, University of California Press, Berkeley, CA.

Jay, M., 2002, 'That visual turn', Journal of Visual Culture 1(87), 87-92. https://doi. org/10.1177/147041290200100108

Jenni, E. \& Vetter, D., 1984, 'ִיְֵ 'ájin Auge', in E. Jenni \& C. Westermann (eds.), Theologisches Handwörterbuch zum Alten Testament. Band II, pp. 259-268, Christian Kaiser, Munich.

Jones, S.C., 2009, Rumors of Wisdom: Job 28 as Poetry, Walter de Gruyter, New York.

Jones, S.C., 2013, 'Corporeal discourse in the book of Job', Journal of Biblical Literature $132(4), 845-863$.

Klein, M., 1984, Love, guilt and reparation and other works 1921-1945, Free Press, New York.

Kochan, L., 1997, Beyond the graven image: A Jewish view, Macmillan, Basingstoke.

Laato, A., 2008, 'Miracles in the Old Testament', in J.H. Ellens (ed.), Miracles: God, Science, and Psychology in the Paranormal, pp. 57-76, Praeger, Westport, CT.

Lacan, J., 1966, Ecrits, Seuil, Paris.

Lacan, J., 1973, Le séminaire, Livre XI: Les quatre concepts fondamentaux de la psychanalyse (1964), J.-A. Miller (ed.), Seuil, Paris.

Lacan, J., 1981, Le séminaire, Livre III: Les psychoses (1955-1956), Seuil, Paris.

Lacan, J., 2004, Le séminaire. Livre X. L’Angoisse, J-A. Miller (ed.), Seuil, Paris.

LaCocque, A., 1996, 'Job and religion at its best', Biblical Interpretation 4(2), 131-153. https://doi.org/10.1163/156851596X00167

LaCocque, A., 2007, 'The deconstruction of Jobs fundamentalism', Journal of Biblical Literature 126(1), 83-97. https://doi.org/10.2307/27638421

Lasine, S., 1988, 'Bird's-eye and worm's-eye views of justice in the book of job', Journa for the Study of the Old Testament 13, 29. https://doi.org/10.1177/03090 8928801304203

List, E., 2013, Psychoanalytische Kulturwissenschaften, Facultas, Vienna.

Loader, J.A., 1992, 'Seeing God with natural eyes: On job and nature', Old Testament Essays 5(3), 346-360.

Neumann, E., 1949, Ursprungsgeschichte des Bewusstseins, Rascher, Zurich.

Newsom, C.A., 2003, 'Dialogue and Allegorical Hermeneutics in Job 28:28', in E.J. van Wolde (ed.), Job 28: Cognition in context, pp. 299-306, Brill, Leiden.

Noegel, S.B., 2007, 'Job III 5 in the light of Mesopotamian demons of time', Vetus Testamentum 57(4), 556-562. https://doi.org/10.1163/156853307X204592

Peels, E., 2008, 'Van horen naar zien. Geloof en ervaring in Job 42:5', in A. Baars, G.C. den Hertog, A. Huijgen \& H.G.L. Peels (eds.), Charis: Theologische opstellen, aangeboden aan prof. dr. JW Maris bij zijn afscheid als hoogleraar aan de Theologische Universiteit te Apeldoorn, pp. 190-197, Groen, Heerenveen.

Pelham, A., 2012, Contested creations in the book of Job: The-world-as-it-ought-andought-not-to-be, Brill, Leiden.

Pope, M.H., 1973, Job: Introduction, translation, and notes, Doubleday, Garden City.

Ross, J., 2010, Human consciousness of God in the book of Job: A theological and psychological commentary, T. \& T. Clark International, London.

Roy, A., 1991, 'The Book of Job: A grief and human development interpretation', Journal of Religion and Health 30(2), 149-159. https://doi.org/10.1007/ BF00988704

Schellenberg, A., 2016, 'Mein Fleisch ist gekleidet in Maden und Schorf (Hi 7,5). Zur Bedeutung des Körpers im Hiobbuch', in G. Etzelmüller \& A. Weissenrieder (eds.), Verkörperung als Paradigma theologischer Anthropologie, pp. 95-126, de Gruyter, Berlin.

Segal, H., 1957, 'Notes on symbol formation', International Journal of Psycho-Analysis 38, 391-397.

Seow, C.L., 2011, 'Orthography, textual criticism, and the poetry of job', Journal of Biblical Literature 130(1), 63-85. https://doi.org/10.2307/41304188

Spronk, K., 1986, Beatific afterlife in ancient Israel and in the ancient Near East, Butzon \& Bercker, Kevelaer.

Stendebach, F.J., 1982, 'עִ "ajin"', in H.-J. Fabry \& H. Ringgren (eds.), Theologisches Wörterbuch zum Alten Testament. Band VI קו - ir, pp. 31-48, W. Kohlhammer, Stuttgart.

Tur-Sinai, N.H., 1967, The book of Job: A new commentary, Kiryath Sepher, Jerusalem. Van der Lugt, P., 1995, Rhetorical criticism \& the poetry of the book of Job, Brill, Leiden.

Van der Lugt, P., 2014, 'Who changes his mind about dust and ashes? The rhetorical structure of job 42:2-6', Vetus Testamentum 64, 623-639. https://doi.org/ 10.1163/15685330-12341169

Van Hecke, P., 2011, From linguistics to hermeneutics: A functional and cognitive approach to Job 12-14, Brill, Leiden.

Van Wolde, E.J., 1994, 'Job 42,1-6: The reversal of job', in W.A.M. Beuken (ed.). The Book of Job, BETL, vol. 114, pp. 223-250, Peeters, Leuven.

Van Wolde, E.J., 2003, 'Wisdom, who can find it? A non-cognitive and cognitive study of job 28:1-11', in E.J. van Wolde (ed.), Job 28: Cognition in context, pp. 1-35, Brill, Leiden.

Widmer, P., 2006. Metamorphosen des Signifikanten: Zur Bedeutung des Körperbilds für die Realität des Subjekts, Transcript Verlag, Bielefeld.

Wilber, K., 1979, 'Eye to eye: Science and transpersonal psychology', ReVision 2, 3-25. 